\title{
Effects of stage of maturity and chop length on the release of cell contents of fresh ryegrass (Lolium perenne L.) during ingestive mastication in steers fed indoors
}

\author{
Anne Boudon ${ }^{a *}$, C. Sinclair Mayne ${ }^{\mathrm{b}}$, Jean-Louis PeYraUd ${ }^{\mathrm{a}}$, \\ A. Scott LAIDLAW ${ }^{c}$
}

\begin{abstract}
${ }^{a}$ Unité Mixte de Recherche, INRA-ENSAR, Production du Lait, 35590 St-Gilles, France ${ }^{b}$ Agricultural Research Institute of Northern Ireland, Hillsborough, Co. Down BT26 6DR, UK ${ }^{\mathrm{c}}$ Plant Testing Station, Applied Plant Science Division, Department of Agriculture and Rural Development for Northern Ireland, Crossnacreevy, Belfast BT6 9SH, UK
\end{abstract}

(Received 7 January 2002; accepted 8 October 2002)

\begin{abstract}
The objective of the trial was to analyse the effects of the mechanical resistance of cell walls and chewing behaviour on the proportion of intracellular constituents (ICs) released during the ingestive mastication of fresh perennial ryegrass (Lolium perenne L.) by steers. The mechanical resistance of cell walls was varied by the stage of maturity ( 15 vs. 30 days of regrowth). Herbage was offered at two chop lengths (long and short) for each stage of maturity, to influence chewing behaviour. Four steers, each fitted with a large ruminal cannula, were fed indoors with the ryegrass in a $4 \times 4$ Latin square design. Ingested boli were collected at the cardia and their IC contents were compared with the IC contents of the grass. The average shear energy was lower with the young grass because of a lower proportion of stems and pseudostems. The eating time per unit of dry matter intake was unaffected by the stage of maturity, but was slightly lower with the short herbages. The nature of the ICs had a strong effect on their release with the larger molecules, or the molecules contained in the chloroplasts, being less rapidly released. The ICs released (as a proportion of intake) ranged from 0.166 for the chlorophyll to 0.612 for the nitrates. The treatments had no effect on the rate of release of the small vacuolar or cytoplasmic ICs. The intracellular nitrogenous fractions, partly in the chloroplast, were released faster in the mature grass, because the animals had to masticate more intensively to obtain a 'swallowable' bolus due to it having a higher shear energy. The release of ICs did not seem to be dependent on the duration of chewing but rather on other parameters of mastication like the force exerted by the jaws, the surface-area of the molars, or the quantity of grass eaten per bolus.
\end{abstract}

rumen digestion / water soluble carbohydrates / nitrogenous compounds / mastication / shear strength

\footnotetext{
* Correspondence and reprints

Tel.: +33 (0)2 23485086 or +33 (0)2 234850 92; fax: +33 (0)2 234851 01; e-mail: boudon@st-gilles.rennes.inra.fr
} 
Résumé - Effet du stade de maturité et de la longueur des brins sur la libération des contenus cellulaires du ray-grass anglais frais (Lolium perenne $\mathrm{L}$.) au cours de la mastication d'ingestion sur des bouvillons nourris à l'auge. L'objectif de cet essai était d'analyser les effets spécifiques de la résistance mécanique des parois et du comportement masticatoire des animaux sur les proportions de constituants intracellulaires (ICs) libérées lors de la mastication d'ingestion chez des bouvillons nourris avec du ray-grass anglais frais (Lolium perenne $\mathrm{L}$.). La résistance mécanique des parois a été modulée par le stade de maturité ( 15 vs. 30 jours de repousse). Pour chaque stade, le comportement masticatoire a été modulé en offrant l'herbe à deux longueurs de brins (long vs. court). Quatre bouvillons, munis d'une large canule ruminale ont été nourris à l'auge en carré latin $4 \times 4$. Des bols d'ingestion ont été collectés directement au cardia et leurs teneurs en ICs ont été comparées avec celles de l'herbe offerte. La résistance mécanique de l'offert a été mesurée comme la moyenne des quantités d'énergie nécessaires pour couper chaque type d'organe végétal, pondérée par les proportions pondérales de chacun des organes dans l'offert. La résistance mécanique a été plus faible avec l'herbe jeune du fait d'une proportion de tiges et de pseudotiges plus faible. La durée d'ingestion par unité d'ingéré n'a pas été affectée par le stade de maturité mais a été légèrement plus faible avec l'herbe en brins courts. La nature de l'IC considéré a eu un fort effet sur sa libération, les ICs chloroplastiques étant plus lentement libérés. La proportion d'ICs libérée a été comprise, en proportion de l'ingéré, entre 0,166 pour la chlorophylle et 0,612 pour les nitrates. La libération des constituants vacuolaires/cytoplasmiques n'a pas été affectée par les traitements. La libération des fractions azotées intracellulaires, partiellement comprises dans les chloroplastes, a été plus rapide avec l'herbe âgée. Les animaux ont mastiqué l'herbe âgée de façon plus intense du fait de sa résistance mécanique plus élevée. La libération des ICs ne semble pas être dépendante de la durée de mastication mais plutôt d'autres paramètres du comportement masticatoire comme la force exercée par les mâchoires, la surface des molaires ou la quantité d'herbe ingérée par bol.

digestion / glucides hydrosolubles / fractions azotées / mastication/ résistance mécanique / rumen

\section{INTRODUCTION}

The intracellular constituents (ICs) of grass represent approximately $50 \%$ of the dry matter, more than $80 \%$ of the nitrogenous compounds and $100 \%$ of the soluble carbohydrates $[19,29]$. Apart from the relative proportion of these constituents in the composition of the grass, their ruminal digestion rate can have an important impact on the microbial activity and the nature and quantity of the terminal products of ruminal digestion. In fresh grass, ICs are enclosed in undegraded plant cells. Thus, the first stage in the process of their digestion is their release from the plant cells. This first stage could be the limiting step in the process of IC digestion and could determine the rhythm of digestion, especially for ICs such as the soluble carbohydrates, whose rate of the next steps, i.e. hydrolysis and fermentation, is very fast [37]. This hypothesis of a delay in the availability of the more rapidly fermentable substrates with animals fed fresh herbage has been supported by Chilibroste et al. [7] who observed a very slow increase of the pool of ruminal volatile fatty acids when animals started to graze.

The release rate of ICs during ingestive mastication and digestion depends primarily on the molecular size of the considered ICs, or the size of the organelles in which they are contained, compared with the diameter of the plant cell wall pores [4-6, 24, 27]. With perennial ryegrass, the stage of maturity has little effect on the proportion of ICs released during ingestive mastication although the eating time per unit of dry matter intake (DMI) is appreciably higher with the most mature grass [4]. The lower efficiency of ingestive mastication with mature grass may be related to a greater mechanical resistance of the plant cell walls. For example, Wright and Illius [38] showed that shear energy is higher with older leaves than with younger leaves of the same tillers. 
The absence of an effect of the stage of maturity of herbage on the release of ICs, in particular during ingestive mastication, could be due to compensation of the stronger resistance of the walls by an increased chewing behaviour, notably through an increase in the eating time per unit of DMI. Alternatively, it could also be explained by a limited variation in the parameters controlling the release of ICs such as the mechanical resistance of the plant cell walls and the chewing behaviour of the animal.

The aim of this experiment was to analyse the specific effects of the mechanical resistance of the cell walls and the chewing behaviour on the dynamics of release of ICs in high quality perennial ryegrass and, to analyse the eventual compensation between these two explanatory factors. To achieve this, the mechanical resistance of plant cell walls was varied experimentally by the stage of maturity and, for each stage, the chewing behaviour of the animals was varied by offering grass indoors with different chop lengths.

\section{MATERIALS AND METHODS}

\subsection{Experimental design, treatments and animals}

Four steers were offered fresh ryegrass (Lolium perenne L.) indoors using a $4 \times 4$ Latin square design. The four treatments involved two stages of maturity, 15 vs. 30 days of regrowth ( 15 vs. 30 ) chopped to give two lengths of grass for each stage of maturity, long or short (L vs. S). The long treatments were obtained by cutting at $4 \mathrm{~cm}$ above ground level. The short treatments were obtained by two successive cuts, one at half the height of the grass above $4 \mathrm{~cm}$ and a second cut at $4 \mathrm{~cm}$ above ground level; the herbage from both cuts was mixed together before feeding.

Each period lasted one week and consisted of two days of adaptation and five days of measurement. The first period began on 12 June 1999 and the fourth period finished on 9 July 1999. The four steers were fitted with rumen cannula. At the beginning of the experiment, their live weights were on average $534 \mathrm{~kg}( \pm 43.7)$.

\subsection{Sward management and animal feeding}

The grass was cut on the same pasture throughout the trial at the Agricultural Research Institute of Northern Ireland experimental farm at Hillsborough. The pasture was sown with Lolium perenne L. cv. Tyrone in 1992. This variety was chosen because it has been shown to reach the heading stage very late in the year [12]. Prior to the experiment, the sward was fertilised with cattle slurry in February and with 74 and $49 \mathrm{~kg} \cdot \mathrm{ha}^{-1}$ of mineral nitrogen and potassium, respectively, in April. The pasture was divided into eight blocks (4 periods and 2 blocks per period) of two plots (2 stages of maturity). Two blocks were used for each period to ensure that the stages of maturity were exactly 15 and 30 days of regrowth on the third or sixth day of the considered period. For a given period, the first block was used to feed the animals for the first four days, and the second block to feed the animals for the remaining three days. For the preparation of the experimental herbage in each block, a 0.12 ha plot was cut 15 days before the third and sixth day of the considered period, and a 0.08 ha plot was cut 30 days before the third and sixth day of the considered period. After each cut, all the plots of the block were fertilised with $30 \mathrm{~kg} \mathrm{~N} \cdot \mathrm{ha}^{-1}$.

The animals were offered fresh grass once per day. The grass was cut in the morning with an Agria mower to avoid laceration, and was fed to the animals at 11:00. Because this experiment was associated with some other measurements, access of the animals to the mangers was limited to one period of three hours. The ad libitum level of 
intake was determined with grass of 30 days regrowth and with free access to the manger, over one week before the trial.

\subsection{Sampling and measurements on herbage}

For the determination of dry matter content of offered grass for each treatment, three representative samples $(1 \mathrm{~kg})$ were oven dried in triplicate $\left(100{ }^{\circ} \mathrm{C}, 24 \mathrm{~h}\right)$ each day before feeding. Four other samples $(500 \mathrm{~g})$ were frozen at $-20{ }^{\circ} \mathrm{C}$ and freeze dried for the determination of cell wall and IC contents.

For the characterisation of grass, grass samples $(2 \mathrm{~kg})$ were collected twice during each period on days 1 and 4 before feeding. A part of each sample was kept fresh (at $4{ }^{\circ} \mathrm{C}$ ) for the measurement of the morphological composition and the shear properties on the day of sampling. The remaining grass was frozen for the measurement of particle size on the following day.

For the morphological separation, $30 \mathrm{~g}$ (fresh weight) of grass were randomly sampled and manually separated into four categories: stems/pseudostems, pseudostems alone, laminae and dead tissue. For each sample, the components in each of the four categories were oven dried $\left(100^{\circ} \mathrm{C}, 24 \mathrm{~h}\right)$. For the measurement of the shear properties, a few particles of each morphological category were randomly selected, soaked in water, measured for length and rolled into bundles of a fixed number of particles, i.e. 3 for the stems/pseudostems, and 5 for the pseudostems alone, the laminae and dead tissue. The particles were aligned within the bundles so that they were sheared at their midpoint. The bundles were sheared with scissors fitted to a texture analyser (Lloyd 500) as described by Wright and Illius [38]. To minimise the friction, the rivet forming the hinge of the blades of the scissors was replaced by a narrow bolt and the blades, originally slightly curved were straightened so that the blades no longer pressed against one another. The force displacement curve measured at the scissors' handles was converted to provide the force and displacement experienced at the cutting surface along the blades of the scissors [38]. Moreover, to eliminate the friction, the curves obtained with the empty device were subtracted from the curves obtained while cutting the samples. After measurement, the fragments were oven-dried and weighed for the calculation of linear weight (DM weight/length), which was assumed to be a gross assessment of the cross sectional area. The measurements were repeated in triplicate for each sample and each morphological category.

For the measurement of length distribution, $30 \mathrm{~g}$ (fresh weight) of frozen grass were randomly sampled, each particle was manually measured and separated into the following categories: $<50-100 \mathrm{~mm}$, 101-150 mm, 151-200 mm, 201-250 mm and $>251 \mathrm{~mm}$. For each sample, the components within the five categories were oven dried $\left(100^{\circ} \mathrm{C}, 24 \mathrm{~h}\right)$.

\subsection{Sampling and measurements on the animals}

The ICs examined comprised the total soluble carbohydrates (TSC), the total intracellular nitrogen and its subfractions (non-protein nitrogen, nitrates and protein nitrogen) and chlorophyll. Non-protein nitrogen, nitrates and total soluble carbohydrates are vacuolar compounds. Protein nitrogen is both cytoplasmic and chloroplastic [23]. Chlorophyll is not of major nutritional interest, but it was used as a tracer for the chloroplastic compounds. Neutral detergent soluble (NDS), which is the complement of the neutral detergent fibres (NDF), was also studied as a gross assessment of the total cell content.

The release of ICs during ingestive mastication was measured by the method described by Boudon and Peyraud [4]. Ingested boli were collected directly at the 
cardia, rinsed and their IC contents were compared with the IC contents of the grass. Ingested boli were collected on two animals on days 1 and 5 of the measurement period and on the two other animals on days 2 and 4. The boli were sampled during the 15 minutes before the main morning meal after a small quantity of grass was fed. The rumen contents of the animal were removed by hand and about $2 \mathrm{~kg}$ of a composite sample of ingested boli were collected directly at the cardia while the animal was eating. The composite sample was gently mixed by hand to avoid rupturing the plant cells that remained intact after ingestive mastication. The remaining grass was then removed from the manger, the rumen of the animal was refilled and the main meal of herbage was offered at 11:00. Each day, from the composite sample from each animal, 3 subsamples of $100 \mathrm{~g}$ were collected for rinsing and determination of IC contents, while 2 subsamples of $100 \mathrm{~g}$ were collected for the determination of dry matter (DM, $100{ }^{\circ} \mathrm{C}, 48 \mathrm{~h}$ ). For the determination of ICs, the 3 subsamples were rinsed with $4 \mathrm{~L}$ of distilled water to remove the ICs released from the plant cells during ingestive mastication. To achieve this, a Buchner funnel was covered with a $100 \mu \mathrm{m}$ mesh nylon cloth and connected to a vacuum pump. The subsamples were gently mixed with a spatula while being rinsed. The rinsing liquid was poured $0.5 \mathrm{~L}$ by $0.5 \mathrm{~L}$, with the subsamples being sucked dry between the washings. The rinsed subsamples were pooled together before freeze-drying.

The effect of ingestive mastication on the morphological composition and the mechanical properties of the ingested boli was also measured. For the morphological separation of the particles of boli, $10 \mathrm{~g}$ (fresh weight) of boli were randomly selected and soaked in water. All the particles longer than $1 \mathrm{~cm}$ were removed from the water and manually separated into lamina, stem, stem/pseudostem, isolated sheaves, and dead tissue. The remaining particles, i.e. particles shorter than $1 \mathrm{~cm}$, and water were filtered on Whatman paper (porosity $11 \mu \mathrm{m}$, Whatman International Ltd., UK) under vacuum. The separation of the particles into two categories was because $1 \mathrm{~cm}$ is the minimum length for measurement of the shear properties of the particle. The material within the five morphological categories and the particles shorter than $1 \mathrm{~cm}$ were oven-dried $\left(100^{\circ} \mathrm{C}, 24 \mathrm{~h}\right)$. Shear energy was measured on particles above $1 \mathrm{~cm}$ by the same method as described for the grass. The number of particles in a bundle was fixed at 10 for the laminae and dead tissue, 5 for the pseudostems and isolated sheaves, and 3 for the stems.

Feed refusals were removed after each meal and weighed to determine intakes. Three samples of $1 \mathrm{~kg}$ per animal per day were oven-dried $\left(80^{\circ} \mathrm{C}, 48 \mathrm{~h}\right)$ for dry matter determination. Feeding behaviour was recorded on days 1, 2, 4 and 5 using bite meters as described by Rutter et al. [28] and weighing mangers. The change in manger weight and the number of jaw movements per unit time were compared to precisely estimate the eating time. One minute was considered as a minute of eating time if more than 10 jaw movements were counted and if the weight of the manger continued to change for at least ten minutes.

\subsection{Chemical analyses}

The analyses were performed on freeze-dried samples of offered grass, refusals, and rinsed ingested boli after grinding through a 1-mm screen. Ash content was determined according to the Association of Analytical Chemists [1] by incineration at $600^{\circ} \mathrm{C}$ for $6 \mathrm{~h}$. The cell wall constituents (NDF, ADF and ADL) were analysed on a Fibertec System (Tecator, Sweden) by the method described by Van Soest [34]. Total N and intracellular N-i.e. total $\mathrm{N}$ minus $\mathrm{N}$ in NDF - were determined by the macro-Kjeldahl method. TSC were measured using the anthrone method as described 
by Thomas [33]. The chlorophyll was analysed by spectrophotometry after extraction with N,N-dimethylformamide ( $24 \mathrm{~h}$ at $4{ }^{\circ} \mathrm{C}$ in the dark) by the method of Inskeep and Bloom [18]. Non-protein nitrogen was analysed by the Kjeldahl method after extraction in water and precipitation of protein with tungstic acid as described by Licitra et al. [21]. Nitrates were analysed using a flow injection analyser by an automated procedure based on the reduction of nitrates to nitrite by a column packed with copperised cadmium granules coupled with a colorimetric reaction.

\subsection{Calculations}

The proportion of IC released in the ingested boli is defined as the difference between the quantity of IC ingested for the bolus and the quantity of IC remaining in the bolus after rinsing divided by the quantity of IC ingested for the bolus. The quantity of IC ingested for the bolus was calculated assuming that the quantity of NDF in the bolus was the same as the quantity of NDF in the eaten grass, before mastication. The final formula is [4]:

ICreleased $=\left(1-\frac{\text { ICboli } \times \text { NDFgrass }}{\text { ICgrass } \times \text { NDFboli }}\right) \times 100$

where ICreleased is the proportion of IC released during eating ( $\%$ of IC intake), ICboli and ICgrass are the IC contents of rinsed boli and offered grass ( $\%$ of dry matter), respectively, and NDFboli and NDFgrass are the NDF contents of rinsed boli and offered grass ( $\%$ of dry matter), respectively.

The shear energy was calculated from the energy expended at the cutting surface of the scissor blades to shear the bundle, divided by the number of particles in the bundle. The energy was calculated by integrating the force displacement curve observed at the cutting surface along the blades [38]. The intrinsic mechanical resistance (IMR, $\mathrm{mJ} \cdot \mathrm{cm} \cdot \mathrm{mg}^{-1} \mathrm{DM}$ ) was defined as the ratio between the shear energy $(\mathrm{mJ})$ and the linear weight $\left(\mathrm{mg} \mathrm{DM} \cdot \mathrm{cm}^{-1}\right)$. The mean shear energy or intrinsic mechanical resistance for a grass sample was the mean of the shear energy or the intrinsic mechanical resistance of each morphological category weighted by its proportion in herbage dry matter.

The unit eating time was defined as the ratio between eating time and the dry matter intake.

\subsection{Statistical analyses}

The data collected on herbage were analysed by analysis of variance according to the GLM procedure of SAS [31]. The model sums of squares were separated into effects due to the treatment and the period. For the morphological separation and the shear properties, the effect of the day of sampling in the period was introduced into the model and the effect of the period was tested on the residual error of the effect of the day within the period.

The data collected on the animals were analysed by analysis of variance with a Latin square design according to the GLM procedure of SAS for a $2 \times 2$ factorial arrangement of treatments. The sums of squares for the treatments were further partitioned into single degree of freedom comparisons for herbage stage of maturity, herbage length (Long vs. Short) and the interaction between herbage stage of maturity and length. For the proportions of ICs released, an additive model was built to test the effect of the nature of the IC. Firstly, the model was used for the NDS, the total intracellular nitrogen and the total soluble carbohydrates. Secondly, the model was applied to the subfractions, chlorophyll, total soluble carbohydrates, protein nitrogen, non-protein nitrogen and nitrates in order to include only independent data in the analysis. In the same way, for the mechanical properties of grass and the particles of boli, additive models were built to test the effect of the 
morphological category or the type of sample (boli or herbage). These models integrated the effect of the treatment, period, animal and the effect of the IC or morphological category or type of sample and its interactions with treatment, period, and animal.

\section{RESULTS}

\subsection{Characteristics of offered herbage}

The mean length of herbage offered was the lowest for the $15 \mathrm{~S}$ treatment, intermediate for the $15 \mathrm{~L}$ and $30 \mathrm{~S}$ treatments and highest for the 30L (Tab. I). The mean length of grass was not significantly different between the $15 \mathrm{~L}$ and $30 \mathrm{~S}$ treatments
$(P>0.10)$ although the proportions of DM in the categories $0-50,51-100,101-150$, 151-200 and 201-250 mm were slightly higher with $15 \mathrm{~L}$ compared to $30 \mathrm{~S}$ and the proportion of $\mathrm{DM}>251 \mathrm{~mm}$ was lower ( 5.7 vs. $18.2 \%$ of dry matter). The $30 \mathrm{~L}$ treatment was characterised by a higher proportion of particles longer than $25 \mathrm{~cm}$ than the three other treatments (54.4 vs. $8.2 \%$ of dry matter).

The dry matter content of herbage was on average $167 \mathrm{~g} \cdot \mathrm{kg}^{-1}$ and was unaffected by the treatment (Tab. I). With an increasing maturity, the NDF contents of herbage increased (489 vs. $501 \mathrm{~g} \cdot \mathrm{kg}^{-1} \mathrm{DM}$ ) whereas the crude protein $(\mathrm{CP})$ content decreased (171 vs. $145 \mathrm{~g} \cdot \mathrm{kg}^{-1} \mathrm{DM}$ ). Length (L vs. S) did not affect the CP content but the NDF

Table I. Mean length and dry matter, cell wall, crude protein and intracellular constituents (ICs) contents of offered herbage.

\begin{tabular}{|c|c|c|c|c|c|c|c|c|}
\hline & \multicolumn{4}{|c|}{ Treatments $^{\dagger}$} & \multicolumn{3}{|c|}{ Contrasts $^{\#}$} & \multirow[b]{2}{*}{$\mathrm{SD}^{*}$} \\
\hline & $15 \mathrm{~L}$ & $15 \mathrm{~S}$ & $30 \mathrm{~L}$ & $30 \mathrm{~S}$ & Maturity & Length & Interaction & \\
\hline \multicolumn{9}{|c|}{ Parameters related to the mechanical properties of herbage } \\
\hline Mean length (mm) & 143 & 101 & 268 & 175 & $* * *$ & $* * *$ & 0.06 & 36.6 \\
\hline Dry matter $(\mathrm{DM})\left(\mathrm{g} \cdot \mathrm{kg}^{-1}\right)$ & 165 & 168 & 167 & 168 & ns & ns & ns & 3.2 \\
\hline $\mathrm{NDF}^{\S}\left(\mathrm{g} \cdot \mathrm{kg}^{-1} \mathrm{DM}\right)$ & 495 & 483 & 503 & 498 & $* *$ & $*$ & ns & 6.52 \\
\hline $\mathrm{CP}^{\S}\left(\mathrm{g} \cdot \mathrm{kg}^{-1} \mathrm{DM}\right)$ & 169 & 173 & 142 & 147 & $* * *$ & ns & ns & 7.6 \\
\hline \multicolumn{9}{|l|}{ Intracellular constituents } \\
\hline $\mathrm{NDS}^{\S}\left(\mathrm{g} \cdot \mathrm{kg}^{-1} \mathrm{DM}\right)$ & 505 & 517 & 497 & 502 & $* *$ & $*$ & ns & 6.52 \\
\hline $\mathrm{TSC}^{\S}\left(\mathrm{g} \cdot \mathrm{kg}^{-1} \mathrm{DM}\right)$ & 196 & 200 & 220 & 213 & $* *$ & ns & ns & 11.03 \\
\hline $\begin{array}{l}\text { Intracellular N } \\
\left(\mathrm{g} \cdot \mathrm{kg}^{-1} \mathrm{DM}\right)\end{array}$ & 22.4 & 22.7 & 17.2 & 16.4 & $* * *$ & ns & ns & 0.72 \\
\hline \multicolumn{9}{|c|}{ Proportions of intracellular $\mathrm{N}$ as: } \\
\hline protein $\mathrm{N}$ & 0.848 & 0.816 & 0.829 & 0.760 & ns & ns & ns & 0.0682 \\
\hline non-protein $\mathrm{N}$ & 0.152 & 0.184 & 0.171 & 0.240 & ns & ns & ns & 0.0682 \\
\hline nitrate $\mathrm{N}$ & 0.009 & 0.007 & 0.012 & 0.013 & $*$ & ns & ns & 0.0036 \\
\hline Chlorophyll (g.kg-1 DM) & 6.99 & 6.58 & 6.54 & 5.79 & ns & ns & ns & 0.727 \\
\hline
\end{tabular}

\footnotetext{
$\dagger$ 15: 15 days of regrowth, 30: 30 days of regrowth, L: Long grass, S: Short grass.

\$ Standard deviation.

$\S$ NDF: neutral detergent fibre; CP: crude protein; NDS: neutral detergent solubles, TSC: total soluble carbohydrates.

$\# *: P<0.05 ; * *: P<0.01 ; * * *: P<0.001$, ns: $P>0.10$.
} 
content was marginally higher with long grass. The average NDS, TSC, intracellular $\mathrm{N}$ and chlorophyll contents were 505, 207, 19.9 and $6.48 \mathrm{~g} \cdot \mathrm{kg}^{-1} \mathrm{DM}$, respectively. With increasing stage of maturity, the intracellular $\mathrm{N}$ content sharply decreased whereas the TSC content increased. The chlorophyll content did not vary. Chopping did not affect the TSC, intracellular $\mathrm{N}$ or chlorophyll contents. The intracellular $\mathrm{N}$ comprised 0.81 protein $\mathrm{N}$ and 0.19 of non-protein $\mathrm{N}$ irrespective of the treatment. The nitrate $\mathrm{N}$ represented 0.01 of the intracellular $\mathrm{N}$, this proportion rising with an increased maturity.
The morphological composition of the offered herbage in proportion of dry matter was: 0.750 laminae, 0.101 stems, 0.114 pseudostems and 0.035 dead tissue. The morphological category had a strong effect on the shear energy $(P<0.0001, \mathrm{SD}=$ 1.967). The average shear energy of the stem, pseudostem, lamina and dead tissue was $13.5,6.5,1.7$ and $0.8 \mathrm{~mJ}$, respectively. The mean shear energy increased from $2.60 \mathrm{~mJ}$ for the young herbage to $4.26 \mathrm{~mJ}$ for the aged herbage. This was related to a decrease of the proportion of laminae from 0.81 to 0.69 and to an increase of the proportion of stems from 0.048 to 0.155

Table II. Morphological composition and shear properties of herbage.

\begin{tabular}{|c|c|c|c|c|c|c|c|c|}
\hline & \multicolumn{4}{|c|}{ Treatments $^{\dagger}$} & \multicolumn{3}{|c|}{ Contrasts $^{\#}$} & \multirow[b]{2}{*}{$\mathrm{SD}^{*}$} \\
\hline & $15 \mathrm{~L}$ & $15 \mathrm{~S}$ & $30 \mathrm{~L}$ & $30 \mathrm{~S}$ & Maturity & Length & Interaction & \\
\hline \multicolumn{9}{|c|}{ Morphological composition (proportion DM) } \\
\hline Laminae & 0.783 & 0.837 & 0.687 & 0.693 & $* * *$ & ns & ns & 0.0600 \\
\hline Stems & 0.054 & 0.041 & 0.160 & 0.149 & $* * *$ & ns & ns & 0.0467 \\
\hline Pseudostems & 0.115 & 0.090 & 0.122 & 0.129 & 0.08 & ns & ns & 0.0359 \\
\hline Dead tissue & 0.048 & 0.032 & 0.031 & 0.030 & ns & ns & ns & 0.0232 \\
\hline
\end{tabular}

Shear energy $(\mathrm{mJ})$

$\begin{array}{lrrrrcccr}\text { Laminae } & 1.76 & 1.68 & 1.63 & 1.64 & \text { ns } & \text { ns } & \text { ns } & 0.326 \\ \text { Stems } & 12.79 & 10.51 & 15.93 & 14.84 & * & \text { ns } & \text { ns } & 3.902 \\ \text { Pseudostems } & 6.27 & 6.60 & 6.75 & 6.23 & \text { ns } & \text { ns } & \text { ns } & 1.367 \\ \text { Dead tissue } & 1.03 & 0.83 & 0.74 & 0.77 & * & \text { ns } & \text { ns } & 0.210 \\ \text { Mean } & 2.74 & 2.45 & 4.41 & 4.10 & * * * & \text { ns } & \text { ns } & 0.830\end{array}$

\section{Linear weight (mg DM·cm $\left.{ }^{-1}\right)$}

$\begin{array}{lcccccccr}\text { Laminae } & 0.78 & 0.77 & 0.68 & 0.79 & \text { ns } & \text { ns } & 0.07 & 0.088 \\ \text { Stems } & 3.03 & 2.45 & 3.39 & 3.18 & * * & * & \text { ns } & 0.451 \\ \text { Pseudostems } & 1.80 & 1.84 & 1.96 & 2.00 & \text { ns } & \text { ns } & \text { ns } & 0.302 \\ \text { Dead tissue } & 0.60 & 0.52 & 0.44 & 0.45 & * * & \text { ns } & \text { ns } & 0.098 \\ \text { Mean } & 1.01 & 0.93 & 1.26 & 1.30 & * * * & \text { ns } & \text { ns } & 0.155\end{array}$

Intrinsic mechanical resistance $(\mathrm{IMR})^{\S}\left(\mathrm{mJ} \cdot \mathrm{cm} \cdot \mathrm{mg}^{-1} \mathbf{D M}\right)$

\begin{tabular}{lllllcccl} 
Laminae & 2.28 & 2.14 & 2.53 & 2.06 & $\mathrm{~ns}$ & 0.07 & $\mathrm{~ns}$ & 0.463 \\
Stems & 4.02 & 4.25 & 4.81 & 4.74 & 0.08 & $\mathrm{~ns}$ & $\mathrm{~ns}$ & 1.004 \\
Pseudostems & 3.62 & 3.69 & 3.41 & 3.24 & $\mathrm{~ns}$ & $\mathrm{~ns}$ & $\mathrm{~ns}$ & 0.765 \\
Dead tissue & 1.71 & 1.52 & 1.68 & 1.79 & $\mathrm{~ns}$ & $\mathrm{~ns}$ & $\mathrm{~ns}$ & 0.413 \\
Mean & 2.47 & 2.35 & 2.95 & 2.58 & $*$ & $\mathrm{~ns}$ & $\mathrm{~ns}$ & 0.451 \\
\hline
\end{tabular}

15: 15 days of regrowth, 30: 30 days of regrowth, L: Long grass, S: Short grass.

Standard deviation.

$\S$ The intrinsic mechanical resistance was defined as the ratio between the shear energy and the linear weight.

$\# *: P<0.05$; **: $P<0.01$; **: $P<0.001$, ns: $P>0.10$. 
(Tab. II). The shear energy of the morphological categories was moderately affected by the treatments, showing an increase for the stems and a decrease for the dead tissue with increasing stage of maturity. The linear weight varied in the same way as the shear energy according to the morphological categories and stages of maturity. Consequently, the effect of the morphological category on the IMR was weaker - with an average value of $4.46,3.49,2.25$ and $1.68 \mathrm{~mJ} \cdot \mathrm{cm} \cdot \mathrm{mg}^{-1} \mathrm{DM}$ for stems, pseudostems, laminae and dead tissue, respectively - but still significant $(P<0.0001, \mathrm{SD}=3.110)$. The mean IMR increased slightly with increasing stage of maturity $(P<0.05)$. The IMR for stems, pseudostems, laminae and dead tissue was not affected by the stage of maturity. Length did not affect the morphological category, nor the shear energy, nor the IMR.

\subsection{Intake and chewing behaviour}

The average dry matter intake was $40.0 \mathrm{~g} \cdot \mathrm{kg} \mathrm{LW}^{-0.75}$, which represents $52 \%$ of the ad libitum level measured in the pre- experimental period (Tab. III). It tended to be lower with the $30 \mathrm{~L}$ treatments compared to the three other treatments (40.7 vs. $37.7 \mathrm{~g} \cdot \mathrm{kg} \mathrm{LW}{ }^{-0.75}$ ).

On average, the unit eating time, number of jaw movements per g of dry matter intake (DMI) and frequency of jaw movements were $39.3 \mathrm{~min} \cdot \mathrm{kg}^{-1} \mathrm{DMI}, 3.3$ per $\mathrm{g}$ DMI and 84.7 per min, respectively. Eating behaviour was unaffected by the stage of maturity except that total eating time was marginally the lowest with the $30 \mathrm{~L}$ treatment (interaction, $P<0.05$ ). Chopping the herbage led to a moderate reduction in the unit eating time $(-2.6 \mathrm{~min}, P<0.05)$ and the number of jaw movements per $g$ of DMI.

\subsection{Effects of ingestive mastication on the release of Ics and the properties of grass particles in the ingested boli}

The proportion of ICs released during ingestive mastication varied widely depending on the particular IC (Tab. IV). The released proportions of intracellular nitrogen

Table III. Treatment effects on food intake and chewing behaviour.

\begin{tabular}{|c|c|c|c|c|c|c|c|c|}
\hline & \multicolumn{4}{|c|}{ Treatments $^{\dagger}$} & \multicolumn{3}{|c|}{ Contrasts $^{\#}$} & \multirow[b]{2}{*}{$\mathrm{SD}^{\ddagger}$} \\
\hline & $15 \mathrm{~L}$ & $15 \mathrm{~S}$ & $30 \mathrm{~L}$ & $30 \mathrm{~S}$ & Maturity & Length & Interaction & \\
\hline \multicolumn{9}{|c|}{ Dry matter intake (DMI) } \\
\hline $\mathrm{g} \cdot \mathrm{kg} \mathrm{LW} \mathrm{W}^{-0.75}$ & 40.5 & 40.1 & 37.7 & 41.6 & ns & ns & 0.06 & 1.89 \\
\hline $\mathrm{kg}$ & 4.51 & 4.45 & 4.16 & 4.62 & ns & 0.10 & $*$ & 0.210 \\
\hline \multicolumn{9}{|l|}{ Ingestion } \\
\hline Total time (min) & 177 & 170 & 166 & 174 & ns & ns & $*$ & 4.8 \\
\hline $\begin{array}{l}\text { Unit eating time } \\
\left(\min \cdot \mathrm{kg}^{-1} \mathrm{DMI}\right)\end{array}$ & 40.7 & 38.3 & 40.5 & 37.8 & ns & $*$ & ns & 2.04 \\
\hline $\mathrm{NbJM}^{\|}$(per g DMI) & 3.45 & 3.28 & 3.47 & 3.14 & ns & $*$ & ns & 0.168 \\
\hline $\mathrm{NbJM}^{\|}$(per min) & 84.5 & 85.6 & 85.2 & 83.4 & ns & $\mathrm{ns}$ & $*$ & 1.08 \\
\hline
\end{tabular}

15: 15 days of regrowth, 30: 30 days of regrowth, L: Long grass, S: Short grass.

Standard deviation.

$\S$ The unit eating time was defined as the ratio between eating time and dry matter intake.

INbJM: number of jaw movements.

$\# *: P<0.05 ; * *: P<0.01 ; * * *: P<0.001, \mathrm{~ns}: P>0.10$. 
Table IV. Proportions of intracellular constituents released during ingestive mastication.

\begin{tabular}{|c|c|c|c|c|c|c|c|c|}
\hline \multirow[b]{3}{*}{$\mathrm{NDS}^{\S}$} & \multicolumn{4}{|c|}{ Treatments ${ }^{\dagger}$} & \multicolumn{3}{|c|}{ Contrasts $^{\#}$} & \multirow[b]{2}{*}{$\mathrm{SD}^{\star}$} \\
\hline & $15 \mathrm{~L}$ & $15 \mathrm{~S}$ & $30 \mathrm{~L}$ & $30 \mathrm{~S}$ & Maturity & Length & nteraction & \\
\hline & 0.295 & 0.318 & 0.388 & 0.362 & $*$ & ns & ns & 0.0375 \\
\hline $\mathrm{TSC}^{\S}$ & 0.385 & 0.374 & 0.431 & 0.390 & ns & ns & ns & 0.0534 \\
\hline Intracellular $\mathrm{N}$ & 0.228 & 0.327 & 0.338 & 0.383 & $*$ & 0.08 & ns & 0.0676 \\
\hline Protein N & 0.188 & 0.260 & 0.384 & 0.338 & $*$ & ns & ns & 0.1054 \\
\hline Non-protein $\mathrm{N}$ & 0.437 & 0.578 & 0.360 & 0.489 & ns & ns & ns & 0.2166 \\
\hline Nitrate N & 0.553 & 0.648 & 0.649 & 0.598 & ns & ns & $*$ & 0.0596 \\
\hline Chlorophyll & 0.147 & 0.148 & 0.202 & 0.165 & ns & ns & ns & 0.0842 \\
\hline
\end{tabular}

$\dagger$ 15: 15 days of regrowth, 30: 30 days of regrowth, L: Long grass, S: Short grass.

\$ Standard deviation.

$\S$ NDS: neutral detergent solubles, TSC: Total soluble carbohydrates.

\#*: $P<0.05 ; * *: P<0.01 ; * * *: P<0.001$, ns: $P>0.10$.

and NDS were lower than for the total soluble carbohydrate component ( 0.33 vs. 0.40 of intake, $P<0.003)$. When considering the subfractions, proportionately less chlorophyll was released ( 0.17 of intake) than protein $\mathrm{N}$ ( 0.29 of intake), which was, in turn, less than the released total soluble carbohydrates and non-protein $\mathrm{N}$ ( 0.430 of intake) with nitrate $\mathrm{N}$ being the most readily released $(0.612$ of intake) $(P<0.0001)$. An increasing stage of maturity increased the released proportions of NDS, intracellular $\mathrm{N}$ and protein $\mathrm{N}$, but the released proportions of the other ICs were unaffected. Chopping did not affect the proportion of ICs released during ingestive mastication.

The mean proportion of particles measuring less than $1 \mathrm{~cm}$ in the boli was 0.382 of the dry matter and was unaffected by the treatments (Tab. V). The mean shear energy of the particles that were larger than $1 \mathrm{~cm}$ in the boli was $2.25 \mathrm{~mJ}$ which was considerably lower than the average shear energy of grass $(3.43 \mathrm{~mJ}, \mathrm{SD}=0.708, P<0.001)$. This was associated with a lower proportion of stem and a lower shear energy of stem and pseudostem in the large particles of the boli compared to the grass. The proportion and the shear energy of laminae were not significantly different in the herbage and boli $(0.750$ vs. $0.714, S D=0.0757$ for the proportion and 1.54 vs. $1.68 \mathrm{~mJ}$, $\mathrm{SD}=0.0757$ for the shear energy, $P>0.05$ ). The mean shear energy of the particles that were larger than $1 \mathrm{~cm}$ in the boli was unaffected by the treatments. The mean shear energy and the shear energy of the different organs were also unaffected by the treatments except for the shear energy of the laminae which had a lower value for young than mature grass. The mean IMR and the IMR of each morphological category of the large particles were not different in the boli and herbage $(P>0.10)$. The mean IMR and the IMR of each morphological category were not affected by the treatment except for the lamina for which the IMR was lower with the young compared to the aged grass in the boli. The mean linear weight and the linear weight of each morphological category were always lower in the large particles of the boli compared to the herbage $\left(0.79\right.$ vs. $1.12 \mathrm{mg} \mathrm{DM} \cdot \mathrm{cm}^{-1}, \mathrm{SD}=0.141$ for the mean, $0.63 \mathrm{vs} .0 .76 \mathrm{mg} \mathrm{DM} \cdot \mathrm{cm}^{-1}$, $\mathrm{SD}=0.060$ for the laminae, $P<0.001$ ). 
Table V. Morphological composition and shear properties of ingested boli.

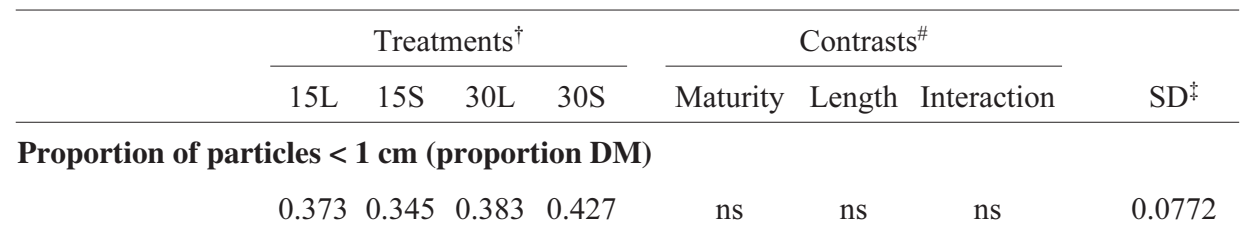

Morphological composition of particles $>\mathbf{1 ~} \mathbf{c m}$ (proportion DM $>\mathbf{1} \mathbf{c m}$ )

$\begin{array}{lcccccccc}\text { Laminae } & 0.808 & 0.727 & 0.706 & 0.614 & 0.08 & \mathrm{~ns} & \mathrm{~ns} & 0.1037 \\ \text { Stems } & 0.026 & 0.022 & 0.081 & 0.099 & \mathrm{~ns} & \mathrm{~ns} & \mathrm{~ns} & 0.0720 \\ \text { Pseudostems } & 0.137 & 0.225 & 0.153 & 0.226 & \mathrm{~ns} & 0.05 & \mathrm{~ns} & 0.0659 \\ \text { Isolated Sheaths } & 0.006 & 0.005 & 0.040 & 0.038 & * & \mathrm{~ns} & \mathrm{~ns} & 0.0188 \\ \text { Dead tissue } & 0.023 & 0.021 & 0.020 & 0.024 & \mathrm{~ns} & \mathrm{~ns} & \mathrm{~ns} & 0.0072\end{array}$

Shear energy of particles $>1 \mathrm{~cm}(\mathrm{~mJ})$

$\begin{array}{lcccccccl}\text { Lamina } & 1.36 & 1.31 & 1.81 & 1.68 & * * * & 0.10 & \text { ns } & 0.092 \\ \text { Stem } & 8.48 & 8.98 & 5.88 & 10.11 & \text { ns } & \text { ns } & \text { ns } & 5.089 \\ \text { Pseudostem } & 3.60 & 3.35 & 3.47 & 2.29 & \text { ns } & \text { ns } & \text { ns } & 1.223 \\ \text { Isolated Sheath } & 0.04 & 0.60 & 0.46 & 1.84 & 0.09 & 0.07 & \text { ns } & 0.587 \\ \text { Dead tissue } & 0.55 & 0.69 & 0.48 & 0.43 & \text { ns } & \text { ns } & \text { ns } & 0.281 \\ \text { Mean } & 1.89 & 1.93 & 2.37 & 2.79 & \text { ns } & \text { ns } & \text { ns } & 0.791\end{array}$

Linear weight of particles $>1 \mathrm{~cm}\left(\mathrm{mg} \mathrm{DM} \cdot \mathrm{cm}^{-1}\right)$

$\begin{array}{lcccccccl}\text { Lamina } & 0.65 & 0.58 & 0.67 & 0.60 & \mathrm{~ns} & * & \mathrm{~ns} & 0.050 \\ \text { Stem } & 2.25 & 2.28 & 1.84 & 2.09 & \mathrm{~ns} & \mathrm{~ns} & \mathrm{~ns} & 0.604 \\ \text { Pseudostem } & 1.21 & 1.12 & 1.15 & 0.89 & \mathrm{~ns} & \mathrm{~ns} & \mathrm{~ns} & 0.320 \\ \text { Isolated Sheath } & 0.12 & 0.55 & 0.49 & 0.59 & \mathrm{~ns} & \mathrm{~ns} & \mathrm{~ns} & 0.195 \\ \text { Dead tissue } & 0.35 & 0.40 & 0.36 & 0.35 & \mathrm{~ns} & \mathrm{~ns} & \mathrm{~ns} & 0.160 \\ \text { Mean } & 0.36 & 0.43 & 0.36 & 0.54 & \mathrm{~ns} & * & \mathrm{~ns} & 0.102\end{array}$

Intrinsic mechanical resistance $(\mathrm{IMR})^{\S}$ of particles $>\mathbf{1 ~} \mathbf{c m}(\mathrm{mJ})$

\begin{tabular}{lcccccccc} 
Lamina & 2.14 & 2.33 & 2.72 & 2.76 & $* *$ & $\mathrm{~ns}$ & $\mathrm{~ns}$ & 0.258 \\
Stem & 3.19 & 3.87 & 3.17 & 5.72 & $\mathrm{~ns}$ & 0.09 & $\mathrm{~ns}$ & 1.629 \\
Pseudostem & 2.92 & 5.24 & 2.93 & 2.42 & $\mathrm{~ns}$ & $\mathrm{~ns}$ & $\mathrm{~ns}$ & 2.481 \\
Isolated Sheath & 1.38 & 1.19 & 1.31 & 2.76 & $\mathrm{~ns}$ & $\mathrm{~ns}$ & $\mathrm{~ns}$ & 0.743 \\
Dead tissue & 1.59 & 1.91 & 1.19 & 1.33 & $*$ & $\mathrm{~ns}$ & $\mathrm{~ns}$ & 0.310 \\
Mean & 2.32 & 2.79 & 2.71 & 2.90 & $\mathrm{~ns}$ & $\mathrm{~ns}$ & $\mathrm{~ns}$ & 0.378 \\
\hline
\end{tabular}

${ }^{\dagger}$ 15: 15 days of regrowth, 30 : 30 days of regrowth, L: Long grass, S: Short grass. $\$$ Standard deviation of the model. ${ }^{\S}$ The intrinsic mechanical resistance was defined as the ratio between the shear energy and the linear weight. ${ }^{*}: P<0.05 ; * *: P<0.01 ; * * *: P<0.001$, ns: $P>0.10$.

\section{DISCUSSION}

\subsection{The release depends on the mean size of the considered IC}

Our results confirm that the nature of the considered IC had a strong effect on its rate of release during ingestion. The differences are related to the size of the IC or of the organelle in which it is contained compared to the size of the pores of the cell wall and are also related to the tissue in which the IC is mainly located. The vacuolar and cytoplasmic ICs, such as the total soluble carbohydrates, the non-protein nitrogen and the nitrates were released in much greater proportions than proteins and chlorophyll that are mainly or totally chloroplastic. This has already been observed [4, 9, 24, 27]. 
The differences in the rate of release between the vacuolar-cytoplasmic and chloroplastic ICs should be due to a selective diffusion of the ICs across the cell walls. The mean size of the pores of the cell wall is 2-6 $\mathrm{nm}$ [10] and for this reason, all the vacuolar and cytoplasmic ICs smaller than this size - like the non-protein nitrogen and most of the water soluble carbohydrates can diffuse across the pores even if that cell wall has not been broken. In contrast, chloroplasts range from 4 to $10 \mu \mathrm{m}$, so the cell wall has to be broken for their release. Two other barriers must be broken to allow the release of ICs from the particles of boli: the plasmalemma and the cuticle. No IC can diffuse across the intact plasmalemma and cuticle, the former because there is no passive transport across the plasmalemma for the ICs considered in this experiment, the latter because the cuticle is covered by waxes and is totally impermeable. The fact that a part of the vacuolar-cytoplasmic ICs was not released during ingestive mastication could mean either that the plasmalemma, or cuticle were not sufficiently broken or that a part of the ICs were retained in the cells by capillary action.

Among the vacuolar and cytoplasmic ICs, the nitrates were the most extensively released, probably because of their particular location in the plant tissue. This result was clearly unrelated to the size of the molecule since nitrates are larger than potassium and Boudon and Peyraud [4] reported that the proportion of potassium released during ingestive mastication is nearly identical to that of the soluble carbohydrates. In this experiment, the nitrates represented only 0.01 of the total nitrogen and it is unlikely that they could accumulate in the vacuoles of the cells of the stems and leaves [19]. It is more likely that they were present only in the crude sap circulating in the xylem. The xylem consists of cells from which the release should be easy because they have lost their protoplasm and solutions in the transpiration stream can pass from cell to cell via their partially or completely perforated terminal walls.

Generally, the proportions of ICs released in this study tended to be low compared to other studies. The release of total soluble carbohydrates, non-protein nitrogen and chlorophyll are quite low [2, 6, 9, $24,27]$. However, the release of protein nitrogen seemed higher than that reported by Boudon and Peyraud [4] but remained lower than estimates by Reid et al. [27], Bryant [6], Doyle [9], Hogan [15], Mangan et al. [24], Austin et Gill [2], Waghorn et Shelton [36]. The rates of release of NDS and intracellular nitrogen were consistent with the rates of release of the other ICs measured in this experiment. The release of intracellular nitrogen was in close agreement with the calculated release based on the average rate of release of protein nitrogen and non-protein nitrogen weighted for their relative proportion in nitrogen (slope, $1.03, \mathrm{SD} 3.88, \mathrm{R}^{2} 0.99$ ). In the same way, the release of NDS was in accordance with the mean release of intracellular crude protein, water soluble carbohydrates and chlorophyll weighed for the relative proportions of intracellular crude protein, TSC and lipids (remainder) in the NDS. The rates of release of NDS and intracellular nitrogen are in accordance with Boudon and Peyraud [4], but are lower than those of other authors [20].

The differences between the rates of release observed in this experiment and in the literature are difficult to explain. The main reason is that the methodologies and plant and animal species used are different from one article to another and that very few direct comparisons of these factors have been published. However, given that Boudon and Peyraud [4] used exactly the same methodology as ours, a comparison with their data was possible. The lower release observed in this experiment compared to Boudon and Peyraud [4] could be due to young steers being used instead of dairy cows and would 
mean that mastication of steers is less efficient than mastication of dairy cows to release the ICs. Even if the feed restriction was high in this study, it may be secondary. It has been widely observed that cattle under feed restriction increase their rate of intake $[14,22]$ i.e. decrease their unit eating time and also decrease the damage done to the grass during chewing [22]. However, the unit eating times measured in this experiment were much higher than those measured by Boudon and Peyraud [4] (39.3 vs. $\left.29.4 \mathrm{~min} \cdot \mathrm{kg}^{-1} \mathrm{DMI}\right)$. This supports the hypothesis of a dominant effect of the type of animal on the rate of release even if this would have to be confirmed by observations on non-restricted animals. With steers, the number of cells crushed by jaw movements or the force exerted at each jaw movement should be weaker. Indeed, in young steers, most of the decidual teeth are largely worn and they are not all replaced, whereas, with 6-year-old dairy cows, all of the final teeth would have appeared but they would not be unduly worn [30]. This would appreciably increase the surface-area of occlusion at each jaw movement. Moreover, it is also possible that the force exerted on the plant cells is higher in the dairy cow compared to the young steer. This is illustrated by the studies of Gordon et al. [13] and Illius et al. [16], which showed that larger animals are able to graze more deeply in swards where the grass has a higher mechanical resistance. Moreover, the crosssection of muscles, which is likely to be correlated with their maximum force, is known to increase with body weight [26].

\subsection{The larger ICs were more affected by the treatments than the smaller ones}

The purely vacuolar/cytoplasmic ICs like the total soluble carbohydrates, the non-protein $\mathrm{N}$ and the nitrates were not affected by the treatments. These ICs can dif- fuse across the cell wall since the plasmalemma and the cuticle are the only barriers which have to be broken to allow the release of these ICs. Thus, it seems that the extent of breakage of the plasmalemma and cuticle was not affected by the treatments.

The release of the intracellular proteins and nitrogen was higher with the aged grass which also had the higher shear energy. This is likely to have been due to a more extensive breakage of the cell wall rather than a modification of the mean size of these constituents between the stages of maturity. Both intracellular nitrogen and protein are composite fractions which contain a vacuolar/cytoplasmic fraction which is easily released and a more slowly released chloroplastic fraction. However, the relative proportions of each fraction did not vary between the treatments in a way to explain the effect of the treatments on the rate of release. The intracellular nitrogen is composed of non-protein nitrogen which is an easily released fraction and of protein nitrogen which is less extensively released. We did not observe any variation in the relative proportion of these two fractions between the treatments. The intracellular proteins contain a fraction of proteins which are more slowly released because they are directly linked to the membranes of the chloroplasts $[4,24]$. It is known that the quantity of these proteins is directly proportional to the quantity of chlorophyll [8]. Since the content of chlorophyll in proportion to that of the protein, was not higher, but even lower with the young grass, the amount of slow releasing chloroplastic protein would not be higher in the young grass. Thus since the mean size of the nitrogenous ICs did not vary and because the chloroplastic fractions can only cross the cell wall which has been fractured, only an effect of the treatments on the quantity of broken cell wall could explain the variation in the rate of release. 


\subsection{The effect of the stage of maturity on the release of nitrogenous fractions could be due to a compensation between the shear energy of the grass and the chewing behaviour}

It has been shown that the rate of release of the ICs is not greatly affected by the stage of maturity [4] as long as the herbage remains vegetative [6]. Our results confirmed this. The principal objective of the present study was to determine if the lack of an effect of the quality of grass, and more specifically of the stage of maturity, could be due to a compensation of a higher resistance of the cell wall by a more severe mastication or due to a similar cell wall resistance irrespective of maturity. Hence, we attempted to obtain an independent variation in the chewing behaviour (by varying chop length) and mechanical resistance of the cell walls. We successfully achieved two herbages with contrasting shear energies (the shear energies were doubled between the young and the aged grass) with a small variation of unit eating time $(+2.6 \mathrm{~min}$ between short and long treatments). Nevertheless, the release during ingestion was not affected by the treatment for most of the ICs and when it was affected - for ICN, protein $\mathrm{N}$ and NDS - it tended to vary inversely with the shear energy of the grass.

The higher release of intracellular nitrogen and protein $\mathrm{N}$ with the aged grass may be due to the fact that the animals had to masticate the grass with the higher shear energy more intensively to obtain a 'swallowable' bolus. Models of mastication developed for humans consider that individuals can modulate their mastication according to the initial consistency of the food to obtain a bolus with a consistency suitable for swallowing [32]. It seems that the oral cavity contains many mechanical captors at the level of the mucosa or of the joint and the muscle of the jaw to react to the consistency of food. No precise definition of this consistency has been given. Because the animals tended to reduce mean shear energy of the particles of the boli for grasses of different initial shear energy to a common level

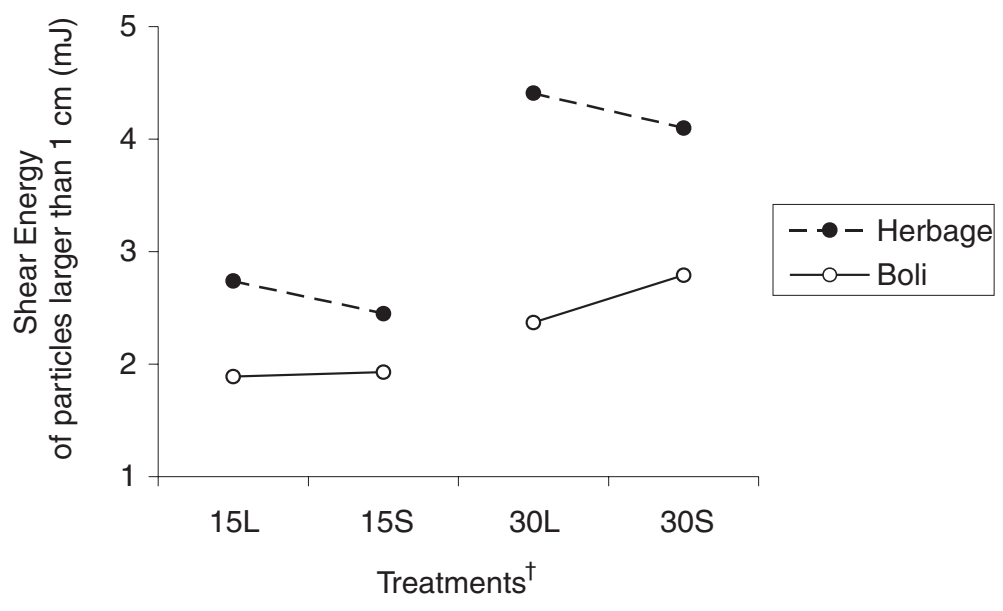

Figure 1. Effect of the treatments on the mean shear energy of particles larger than $1 \mathrm{~cm}$ in herbage and ingested boli.

$\dagger$ 15: 15 days of regrowth, 30: 30 days of regrowth, L: Long grass, S: Short grass. 
(Fig. 1) and because the grass with the higher shear energy can exert a higher resistance during mastication, the shear energy may be one of the criteria in achieving a 'swallowable' consistency. For the same reason, the particle size [17] and the dry matter content [11] could be other criteria. It is noteworthy in this study that during ingestive mastication, the animals reduced and tended to standardise both the shear energy, and the linear weight of particles in the boli compared to the grass. However, the IMR was not different in the grass and in particles of boli. This agrees with Mtengeti et al. [25] who showed that during mastication of perennial ryegrass by sheep, the width of leaf particles was reduced proportionately more than their length. This is probably due to the fact that the propagation of the mechanical ruptures is easier between than across the veins of grass laminae [35]. In this study, the fact that neither the unit eating time, nor the frequency of the jaw movements were affected by the treatments suggests that the animals modulated some other parameters of mastication to reduce particle shear energy and linear weight more in the aged than in the young grass. Possible factors include the amplitude of each jaw movement or the quantity of material chewed i.e. the quantity of grass per bolus. Animals which are fed hay decrease the quantity per bolus with increasing forage maturity [3].

The animals could compensate for higher shear energy by modifying the above mentioned parameters of mastication. Shear energy is a measurement of the mechanical resistance of the particle whereas the IMR is a measurement of the intrinsic mechanical resistance of the cell wall. Among both parameters, the IMR may be the more direct explanatory parameter of the release of ICs. Since IMR and the shear energy are correlated, increased intensity of chewing due to a higher shear energy would also compensate for a higher IMR. The variation of the IMR in this ex- periment was small and the weak effect of the stage of maturity on the release of ICs may be due to the relatively narrow variation in the mechanical resistance of the plant cell walls and, hence, in chewing behaviour. The idea of a compensation of a higher IMR by the chewing behaviour remains to be confirmed using herbage varying more widely in maturity or different species to obtain a wider range of IMR.

\section{CONCLUSION}

During ingestive mastication, the release of chloroplastic ICs, i.e. mainly nitrogenous compounds, is more sensitive to the mechanical resistance of the herbage and to the chewing behaviour of the animals than the release of the vacuolar-cytoplasmic ICs. When variations were observed, the release was higher with the herbage with the more resistant cell walls because the animals had to masticate it more thoroughly to obtain a 'swallowable' bolus. However, the variations observed in this experiment with vegetative ryegrass were low and should not explain a lot of variability in the dynamics of ruminal fermentation or in the nature of the terminal products of digestion. The ingestive mastication of steers seems less efficient to release the ICs than that of dairy cows. This result would have to be confirmed on non-restricted animals and it would be worth evaluating the consequences on the dynamics of digestion.

\section{ACKNOWLEDGEMENTS}

The authors wish to thank the staff of the Applied Plant Science Division, DARDNI, and the staff of the dairy unit, ARINI, for their enthusiasm and commitment. Thanks are also due to the laboratory staff of the ARINI and the UMRPL, INRA. We also acknowledge Miss A. Acosta of the Facultad de Agronomia, Universidad de Buenos Aires for the provision of the chlorophyll data. 


\section{REFERENCES}

[1] Association of Analytical Chemists, Official methods of analysis of AOAC International, 16 th ed., Volumes 1 and 2, AOAC International, Gaithersburg, Maryland, 1995.

[2] Austin A.R., Gill M., Effects of ensiling on the release of soluble carbohydrates and nitrogen during eating and its relationship to intake and nitrogen retention, in: Thomson D.J., Beever D.E., Gunn R.G. (Eds.), Forage protein in ruminant animal production, Occasional publication No. 6 - British Society of Animal Production, BSAP, Thames Ditton, Surrey, UK, 1982, pp. 187-188.

[3] Beauchemin K.A., Iwaasa A.D., Eating and ruminating activities of cattle fed alfalfa and orchardgrass harvested at two stages of maturity, Can. J. Anim. Sci. 73 (1993) 79-88.

[4] Boudon A., Peyraud J.-L., The release of intracellular constituents of fresh ryegrass (Lolium perenne L.) during ingestive mastication in dairy cows: effect of intracellular constituent, season and stage of maturity, Anim. Feed Sci. Technol. 93 (2001) 229-245.

[5] Boudon A., Peyraud J.-L., Faverdin P., The release of cell contents of fresh grass (Lolium perenne L.) during digestion in dairy cows: effect of intracellular constituents, season and stage of maturity, Anim. Feed Sci. Technol. (in press).

[6] Bryant A.M., The release of plant cell contents and its relation to bloat, Proc. N.Z. Soc. Anim. Prod. 24 (1964) 54-66.

[7] Chilibroste P., Tamminga S., Van Bruchem J., Van der Togt P.L., Effect of allowed grazing time, inert rumen bulk and length of starvation before grazing on the weight, composition and fermentative end-products of the rumen contents of lactating dairy cows, Grass For. Sci. 53 (1998) 146-156.

[8] Douillard R., Protéines de feuille et rubisco, in: Godon B. (Ed.), Protéines végétales, Lavoisier, Paris, 1996, pp. 173-222.

[9] Doyle J.J., The effect of chewing by sheep on the release of nitrogen and soluble carbohydrates from plant cells, Aust. J. Exp. Agric. Anim. Husb. 7 (1967) 318-320.

[10] Gardner P.T., Wood T.J., Chesson A., Stuchbury T., Effect of degradation on the porosity and surface area on forage cell walls of differing lignin content, J. Sci. Food Agric. 79 (1999) 11-18.

[11] Gill J., Campling R.C., Westgarth D.R., A study of chewing during eating in the cow, Brit. J. Nutr. 20 (1966) 13-23.

[12] Gilliland T.J., Grass and clover: recommended varieties for Northern Ireland 1998/99, Department of Agriculture of Northern Ireland, Belfast, 1998.
[13] Gordon I.J., Illius A.W., Milne J.D., Sources of variation in the foraging efficiency of grazing ruminants, Funct. Ecol. 10 (1996) 219-226.

[14] Greenwood G.B., Demment M.W., The effect of fasting on short-term cattle grazing behaviour, Grass For. Sci. 43 (1998) 377-386.

[15] Hogan J.P., The digestion of food by the grazing sheep. IV. The effect of mastication on the release of soluble plant nitrogen, Aust. J. Agric. Res. 16 (1965) 855-862.

[16] Illius A.W., Gordon I.J., Milne J.D., Wright W., Costs and benefits of foraging on grasses varying in canopy structure and resistance to defoliation, Funct. Ecol. 9 (1995) 894-903.

[17] Inoué T., Brookes I.M., John A., Kolver E.S., Barry T.N., Effects of leaf shear breaking load on the feeding value of perennial ryegrass (Lolium perenne) for sheep. II. Effect on feed intake, particle breakdown, rumen digesta outflow and animal performance, J. Agric. Sci. (Camb.) 123 (1994) 137-147.

[18] Inskeep W.P., Bloom P.R., Extinction coefficients of chlorophyll $a$ and $b$ in N,NDimethylformamide and $80 \%$ acetone, Plant Physiol. 77 (1995) 483-485.

[19] Jarrige R., Grenet E., Demarquilly C., Besle J.-M., Les constituants de l'appareil végétatif des plantes fourragères, in: Jarrige $R$. Ruckebusch Y., Demarquilly C., Farce M.-H., Journet M. (Eds.), Nutrition des ruminants domestiques : ingestion et digestion, INRA Editions, Paris, 1995, pp. 25-31.

[20] John A., Ulyatt M., Importance of dry matter content to voluntary intake of fresh grass forages, Proc. N.Z. Soc. Anim. Prod. 47 (1987) 13-16.

[21] Licitra G., Hernandez T.M., Van Soest P.J., Standardization of procedures for nitrogen fractionation of ruminant feeds, Anim. Feed Sci. Technol. 57 (1996) 347-358

[22] Luginbuhl J.-M., Pond K.R., Burns J.C., Russ J.C., Effects of ingestive mastication on particle dimensions and weight distribution of coastal bermudagrass hay fed to steers at four levels, J. Anim. Sci. 67 (1989) 538-546.

[23] Mangan J.L., The nitrogenous constituents of fresh forages, in: Thomson D.J., Beever D.E., Gunn R.G. (Eds.), Forage protein in ruminant animal production, British Society of Animal Production, Surrey, 1982, pp. 25-40.

[24] Mangan J.L., Vetter R.L., Jordan D.J., Wright P.C., The effect of the condensed tannins of sainfoin (Onobrychis viciaefolia) on the release of soluble leaf protein into the food bolus of cattle, Proc. Nutr. Soc. 35 (1976) 95A-97A.

[25] Mtengeti E.J., Wilman D., Moseley G., Physical structure of white clover, rape, spurrey and perennial ryegrass in relation to rate of intake by sheep, chewing activity and particle breakdown, J. Agric. Sci. (Camb.) 125 (1995) 43-50. 
[26] Peters R.H., The ecological implications of body size, Cambridge University Press, Cambridge, UK, 1983.

[27] Reid C.S.W., Lyttleton J.W., Mangan J.L., Bloat in cattle: XXIV. A method of measuring the effectiveness of chewing in the release of plant cell contents from ingested feed, N.Z. J. Agric. Res. 5 (1962) 237-248.

[28] Rutter S.M., Champion R.A., Penning P.D., An automatic system to record foraging behaviour in free-ranging ruminants, Appl. Anim. Behav. Sci. 54 (1997) 185-195.

[29] Sanderson M.A., Wedin W.F., Nitrogen in the detergent fibre fractions of temperate legumes and grasses, Grass For. Sci. 44 (1989) 159-168.

[30] Sautet J., L'appareil digestif et ses adaptations, in: Jarrige R., Ruckebusch Y., Demarquilly C., Farce M.-H., Journet M. (Eds.), Nutrition des ruminants domestiques: ingestion et digestion, INRA Editions, Paris, 1995, pp. 183-222.

[31] Statistical Analysis Systems, SAS/STAT User's Guide for Personal Computers, Version 6, SAS Institute, Cary, NC, 1987.
[32] Thexton A.J., Mastication and swallowing: an overview, Brit. Dent. J. 173 (1992) 197-206.

[33] Thomas T.A., An automated procedure for the determination of soluble carbohydrates in herbage, J. Sci. Food Agric. 28 (1977) 639-642.

[34] Van Soest P.J., Laboratory methods for evaluating the energy value of feedstuffs, in: Swan H., Lewis D. (Eds.), Feed and energy sources for livestock, Butterworths, London, 1976.

[35] Vincent J.F.V., The influence of water content on the stiffness and fracture properties of grass leaves, Grass For. Sci. 38 (1983) 107-114

[36] Waghorn G.C., Shelton D., Red clover composition, resistance to shear and effect of maturity when fed to sheep, Proc. Nutr. Soc. N.Z. 13 (1988) 134-139.

[37] Weisbjerg M.R., Hvelpund T., Bibby B.M., Hydrolysis and fermentation rate of glucose, sucrose and lactose in the rumen, Acta Agric. Scand. Sect. A, Anim. Sci. 48 (1998) 12-18.

[38] Wright W., Illius A.W., A comparative study of the fracture properties of five grasses, Funct. Ecol. 9 (1995) 269-278. 